\title{
Celtic Language as a Primary Branch of Ancient Japhetic or Turanian Language
}

\author{
Aygun Kosayeva ${ }^{1}$ \\ ${ }^{1}$ Department of Linguoculturology, Azerbaijan University of Languages, Baku, Azerbaijan \\ Correspondence: Aygun Kosayeva, Department of Linguoculturology, Azerbaijan University of Languages, Baku, \\ Azerbaijan. E-mail: aygun_lia@hotmail.com
}

\author{
Received: May 9, 2014 Accepted: September 1, 2014 Online Published: October 1, 2014 \\ doi:10.5539/ijel.v4n5p70 URL: http://dx.doi.org/10.5539/ijel.v4n5p70
}

\begin{abstract}
This article reports on a study of words affinity in Irish, Azerbaijani and other Turkic languages. In spite of Irishmen's migration from territory of ancient Azerbaijan to Asia Minor and further to the British Isles, they could preserve not only culture, but also their language in a new motherland. The present paper discloses semantic similarities and etymology of several words in Irish, Gaelic, Welsh and other Turkic languages. Celtic language was a primary branch of ancient Japhetic or Turanian language, because the meaning of several words in Celtic and Turkic languages proves a kinship between Celts and Turkic nations.
\end{abstract}

Keywords: Celtic, Turkic, Saca, Japhetic, semantic similarity, affinity

\section{Introduction}

The history of language development is closely connected with a history of people's progress. Therefore, it is impossible to study the formation and development of this or another language in separation from deep studying of history of development of state and people.

Celtic language family includes: Irish, Scottish, and Manx (Gaelic languages) and Welsh, Breton and Cornish (Brythonic languages). The Celtic language family is a branch of the larger Indo-European family, which leads some scholars to a hypothesis that the original speakers of the Celtic proto-language may have arisen in the Pontic-Caspian steppes.

\section{Material Studied}

John Macpherson in his detailed work devoted to Scots mentioned the fact of early migration of tribes from the Caspian Sea: "The first race of Asiatics, in the progress of their migrations, were naturally separated by the Caspian Sea; some directing their course to Tartary, and others to Asia Minor. Of the Tartar race are descended the Scandinavians, under which name I compared the Danes, Swedes, western Russians, and Poles: the Celts of Gaul, Italy, and Spain, were a colony from the lesser Asia" (Macpherson, 19, 20).

It is known about the theory of Thor Heyerdahl that the ancestors of Scandinavian people came from Caucasus, from territory of Azerbaijan. In one of his stories T. Heyerdahl told that a blond-hair mummies, discovered on the territory of China was of the Celtic origin: "When the Chinese archeologists conducted radio-carbon dating, they determined that the mummies were of Nordic type dating from 1,800 to 1,500 years BC. These mummies were dressed in cloth that had been woven, and the colors and the woven pattern were of a very specific type. The Chinese themselves studied the mummies and then invited American experts to study the clothing who determined that the weave and coloring were typical of the Celts of Ireland. However, this made no sense at all. Then we contacted Ireland to get their sagas, and their written saga says that their ancestors were Scythians. So, again, their roots come back here to the Caucasus"... Chinese archaeologists who theorize (probably wrongly) that they came from northern Europe because they were tall, blond, blue-eyed and with Caucasian features. According to modern scholars in Azerbaijan, there used to be a strong blond and fair-skinned element in the aboriginal Azeri population, as illustrated by the stone-age hunters at the Gobustan Museum. Subsequent invasions by Romans and Arabs have somewhat modified the original Azeri type (Blair, 66, 52).

In work of J. Macpherson an interesting fact about origin of Scots and Picts from Albanians is mentioned: "The Scots came into Ireland, from Scythia, in the fourth age of the world; they and the Picts had one common origin; and those two nations were descended from the Albanians" (Macpherson, 15). 
One can suppose that through the Caspian Sea, from territory of ancient Azerbaijan ancestors of Scots and Picts migrated to the British Isles, because Albanians which were mentioned by J. Macpherson settled territories of the Caucasus Albania. It occupied lands from the River Aras in the south till the mountains of Greater Caucasus on the north, from Iberia on the west till the Caspian Sea on the east (History of Azerbaijan, 112).

\section{Affinity between Celts and Ancient Azerbaijanis}

There are several facts indicating on affinity between Celts and ancient Azerbaijanis. Moses of Kalankatuyk, an author of "History of Albania" wrote in his work that Gomer was a second ruler of Caucasus Albania (ancient Azerbaijan) after his father Japhet (Tunchay, 11).

Canon Bourke supposed that Gael, or Irish are sons of Japhet, and consequently Turanians (Bourke, 7).

Hebrew, Christian and Muslim sources unanimously accepted that Turks are descendants of Japhet, son of Noah. Mahmud al-Kashgari wrote that: "Turks have 20 branches. The race of each reaches Prophet Noah's son Japhet, his son Turk". Written sources, archeological and ground monuments indicate territory of Azerbaijan as a place where Prophet Noah lived. Indisputable and basic evidence is a tomb of Prophet Noah in Nakhchivan (Azerbaijan). Ptolemy mentioned that Noah lived and died in Naxouana, i.e. Nakhchivan (36).

Pezron, an abbot of La Charmoye in France wrote: “Japhet was the eldest of Noah's three sons. This patriarch's eldest son was Gomer, the founder of a people, and who they could be but the Gomarians, from whom, according to Josephus, the Celtae or Gauls descended. And if Gomer be the true stock of the Gauls, as I have already made out by so many proofs and authorities, they must have a language quite different from other people and that was the Celtic tongue. But to carry this name no farther, which indeed properly appertained to no other than the European provinces towards the west, it was at first the language of the Gomarians in Asia, then of the Sacae, afterwards of the Titans, and also of the Cimri or Cummerians. After all which, that is a series of many ages, it became at last the language of the Celtae, who were better known by the name of Gauls" (Maclean, 27-28).

Therefore, by Asia one can assume territory of ancient Azerbaijan, because tribes of Sacae and Gomarians or Cimmerians settled those lands in remote ages.

According to Sharon Turner Welsh people still call themselves Cymry (pronounced Kumri), who are descendants of Cimmerians (Turner, 31).

F. Agasioglu reckons that: "Cimmerians, who participated in formation of Azeri-Turks, from shores of Sea of Azov in VIII c. B.C. came to Southern Caucasus and Western Anatolia and created here a kingdom. According to several sources Cimmerian tribes began to appear in Anatolia in times of Homer or in more ancient times. Toponyms connected with Cimmerian tribes one can find not only on territory of Azerbaijan and Iranian Azerbaijan (Qamarli, Kamarli, Kamar, Komar, Khomarlu), but also on territories of other countries: Turkey (Komarlar, Komarli, Kamar-ushagi), Republic of Georgia (Ashagi Gamarli, Yukhari Qamarli, Gomareti, Didi-Gomareti), Uzbekistan (Zaraut-Kamar rock) and Turkmenistan (Kamar, Kamarli) (Agasioglu. Ancient Turkic land, 3-5).

According to Charles Vallancey the origin of a word "Celt" is from tribes of Scytae: “... and it is not improbable that the word Celtae is likewise a corruption of Scytae, in process of time probably called Scheltae or Skeltae, Keltae or Celtae" (Vallancey. An Essay on the antiquity, 9-10).

We can propose that the word Scytae is the Scythian tribes of Sacae, which later could change its name to Gaul with omission of a letter "s" at the beginning. As it was mentioned by Pezron, the Celtic language was language of Gomarians, Sacae and Cimri or Cimmerians. If the previous name of Celts was Sacelt or Sagaul then it is obvious to find similar words in Irish, Azerbaijani and other Turkic languages because Sacae tribes settled territories of Azerbaijan, Turkey, Middle Asia in past. It is explained by the fact that in ancient times (VIII c. B.C.) on the territory of Azerbaijan there existed a region Sacasena named so by Sacae/Saca tribes which settled it. Name of Azerbaijani town Sheki formed from the same Saca/Shaka tribes which inhabited territory of Azerbaijan long before Christ. The Saca tribes occupied territories of modern Gandja - Gazakh region (the Azerbaijan Republic) named in antique sources as Sacasena. Byzantine author Menander in 568 year wrote that Turks in ancient times were called Saca. Among Turkic people one can find names like saka and shaka: one of Kazakh tribes' name is shaga, Uzbeks have shakay, shekey, Kyrgyz - sakha, saka, Turkmen - shaka (Azerbaijani toponyms, 568).

Undoubtedly, regions Bilasakan and Sisakan mentioned in sources of Albanian period were bound with ethnonym Saca. The word "Saca" in the form of toponym recorded in several Azerbaijani towns and regions like Sheki, Zagatala, Sakandara (Gakh region) (Azerbaijan History, 45). 
According to I.M. Diakonov, first time the territory of Saca tribes were mentioned in 820 B.C. as Sagbit near to Hamadan. In that period the ruler of this area was Khanaziruk. The second territory probably is Zikertu and many experts make it equal to the territory Sagarti $(\Sigma \alpha \gamma \alpha \rho \tau i o l)$ mentioned by Herodotus and Ptolemy. Region Zikertu was situated on the south-east from Tebriz, between Lake Urmia and the Caspian Sea (Agasioglu. Ancient Turkic land, 17).

In Turkmenistan an ethnonym saka one can meet within the tribe of salir and bayat. Sacas through territory of Azerbaijan went to the south-east part of Anatolia and this fact is proved by several settlements mentioned in Assyrian sources. So, in XII c. B.C. from Lake Van to the south there were two Saga ( ${ }^{\text {uru }}$ Saga) villages and in VIII c. B.C. on upper stream of Tigris river there was a settlement Saka ( $\left.{ }^{\mathrm{uru}} \mathrm{Sakka}\right)$ (Agasioglu. Ancient Turkic land, 16-18).

In ancient times name of Upper Garabakh was Artsak which occupied territory of Azerbaijan. Artsak is of Turkic origin and consists of two words "art" "mountainous area", "a hill" and ethnonym "saca", which means "Hill of Sacas" or "Mountainous area of Sacas". In Irish language a word "ard" means "a height", "top", "summit" and corresponds with Turkic word "art" (O'Reilly, 35).

The interesting fact one can notice in toponyms of several European towns where Celts inhabited in remote ages. Actually, in names of toponyms instead of a word "celt" one can find a word "sac/seg". Thus, in Spain towns Segovia, Segeda, Segonita exemplify this fact. The next example of Celtic settlement is a town Sisak in Croatia. We came to a conclusion that Celts belonged to Saca tribes and traces of their settlement noticed in above mentioned European towns in the form of Seg/Sak.

Thus, native land of Celts is reputed territories of Azerbaijan (Sacasena, Bilasakan, Sisakan, Artsak, Sheki, Zakatala, Sakandara), Iranian Azerbaijan (Sagbit, Zikertu), Turkey (Saga, Saka), also territories of Middle Asia, where lived tribes of saka/shaka. From those territories they migrated to Asia Minor, further to Western Europe and to the British Isles.

Modern Irish people call themselves Eirionnach/Erionnach but their country Erin. Their neighbours Highlanders of Scotland are called Albanach and their country Alban.

The author of "History of Albania" Moses of Kalankatuyk mentioned Aran, a ruler of Albanians, who was the descendant of Japhet from blood of Sisakan (Sunik). He reckoned words Alban and Aran synonymous and considered both nations as kindred tribes (Kazimov, 386-387).

We propose that Alban and Aran tribes which settled territory of Azerbaijan were ancestors of Irish people or Erionach and Highlanders of Scotland or Albanachs. A region Sacasena, which was mentioned above, was included in the territory of Caucasus Albania. Both tribes Aran and Alban inhabited that territory where ruled Gomer the son of Japhet. Their language was Gomarian, which later became a language of Celtae or Sacelt/Saca. It could be explained not only by kinship between them but the language factor also plays an important role.

\section{Research Methodology}

We have used in this article historical and comparative typological methods in the investigation of the position of the words in Celtic, Azerbaijani and Turkic languages.

\section{Semantic Similarities between Celtic and Turkic Words}

In Celtic and Turkic languages there are several similar notions which are expressed in:

a) Terms of kinship;

b) Words connected with human feelings, state; age;

c) Words connected with "fire", "light";

d) Somatic vocabulary;

e) Words with notion of "death", "attack", "seizing"

f) Words which express titles;

g) Words with notion of "clothes";

h) Words which express "plow", "agriculture"

Terms of kinship in Celtic language are the following:

Scottish Gaelic (Sc.Gael.), Irish athair 'father', tad in Welsh. In ancient Turkic (anc.Turk.), Azerbaijani (Azer.), Kazakh (Kaz.), Kyrgyz (Kyrg.), Tatar (Tat.), Turkmen (Turkm.) a word ata means 'father', in Uzbek (Uzb.) it is 
ada 'dad, father' (Sevortian, words with vowels, 200-201). One can suppose that in Sc.Gael. and Irish a word athair morphologically consists of two words atha and $i r$. The first component of the word atha is similar to Turkic ata 'father'. The second component $i r$ has an explanation in Turkic languages. The word "ir/er/ar" in Turkic languages has a meaning of 'a man', 'warrior', 'husband'. So, the whole word athair means 'a father-man' or 'a father-husband'. In Welsh tad 'father' has its equivalent in Azer. dialect dada 'father'. The word "dada" is spread in regions of Azerbaijan like Gandja, Gazakh and in Republic of Georgia (Borchali or Kvemo-Kartli region), mostly where ethnic Azeris live. From history of Azerbaijan it is known about famous names like Ata and Dada among Turkic tribes, who settled territories around Lake Urmia (Iranian Azerbaijan) in remote ages (History of Azerbaijan, 43).

Sc.Gael., Irish mathair 'mother', mam in Welsh. In dialects of Turkm., Azer., Turk., Kyrg., Kaz., Uzb. a word mama means 'mother' and is similar to Welsh mam. Actually mama in Turkic languages is similar to notion of 'a nursing mother' from general Turkic word mama 'a breast' (Etymological dictionary of Turkic languages: with letters "L", "M", “N", "P", “S", 189).

In dictionary of MacBain a word mam is 'a large round hill', Irish mam, 'mountain', Middle Irish mamm, 'breast', 'pap' (37). John Milne gives an explanation to the name of a hill in Aberdeenshire Allt Carn a' Mhaim as 'burn of the breast-shaped hill', where Allt, burn; carn, hill; $a^{\prime}$, of the; mhaim, gen. asp. of mam, something in shape like a woman's breast (Milne, 8). So, one can see a semantic similarity between Gaelic mam 'a large round hill', Irish mam, 'mountain', Middle Irish mamm, 'breast', 'pap' and Azer. mama 'a breast', Turk. meme, Tat. memi.

Ch. Vallancey supposes that Irish word mathar 'mother' is formed by attaching particle $\mathrm{em}$ to the word athar 'father' and as a result a word becomes emathar, i.e. a woman of the athar. The author gives more ancient forms of Irish words am 'mother' and athar 'father' which are not presented in modern Gaelic or Irish dictionaries (Vallancey. Prospectus of a dictionary, 156, 161). Z. Hasanov making reference to Mahmud al-Kashgari states that a word uma in ancient Turkic language means 'mother', um is 'stomach', 'womb'. Umay was a name of Turkic Goddess of fertility and was venerated by ancient Turks (Hasanov, 313).

Sc.Gael., Irish balach 'a boy', bala 'budding' in Welsh (37) have semantic similarity in Azer., Turkm., Tat., Kaz. where a word bala means 'a baby', 'a child', while in Uzb. and Kaz. dialects a word bala is 'a boy' (Sevortian, with letter "B", 47-48).

Words like baban/boban in Sc.Gael. and Irish means 'a baby' (37). In Irish babach is 'childishness, innocence' (O'Reilly, 41) which is equivalent to Turk. bebek, bebe 'a baby', Tat. bebe (Sevortian, with letter "B", 95).

Sc.Gael. oglach is 'a youth', 'a servant', Irish yglach, Old Irish yclach, from yg and suffix-lach. A word og in Sc.Gael. means 'young', Old Irish yc, yac, Welsh ieuanc (37). In dictionary of O'Reilly together with a word oglach 'a youth', 'a servant' the author gives an example of Turkish word oghlan which means 'a young man' (O'Reilly, 391). In anc. Turk. oylan is 'a child', 'a boy', in Azer., Turk. oglan 'a boy', 'a young man', 'lad', Kyrg. oglan 'unmarried lad', Uzb. oglan 'a young warrior'. In Tuvin language oglak is 'a child', 'a boy'. Etymology of a word oglan according to G. Vambery is that the core meaning of a word is not 'a child of a human', but 'a calf', 'offspring' in general. In the word oglan a syllable $o k$, og is adjoining form to the verb tok 'be born', which lost its dental anlaut (Sevortian, words with vowels, 411-412).

Irish carad, in Sc.Gael. caraid 'a friend', Irish caradas 'friendship', 'alliance', Old Irish cara, Welsh car 'a friend', 'a relation' (37). Irish caradas 'friendship', 'alliance' coincides with Azer., gardash, Turk. kardesh 'brother', 'ally' (O'Reilly, 103).

G. Geybullayev mentions that Scythians of the Black Sea region had a king by name of Kharasin. This name consists of anc. Turk. word karu 'dear', 'nice', 'darling' and sin, chin, shin, which means 'alike'. There are several examples connected with word karu and sin, chin in historical names of Turkic rulers. For example, name of a ruler of Eastern Hunn's principality was Kunhchin and a real name of Genghis Khan was Timuchin (Geybullayev, History of formation, 110).

So, Sc.Gael. caraid, Irish carad and Welsh car 'a friend' and ancient Turkic word karu 'nice' has semantic similarity and are used in the meaning of 'a person who is close and dear to somebody'.

Words connected with human feelings in Scottish Gaelic are expressed in word achlan 'lamentation'; éigh 'a cry', Irish éigheamh, Old Irish égem, Celtic root eig (37). In Turkic languages one can meet semantic similarities with Celtic ones. For example, in Turkm., Azer agi means 'a cry', 'lamentation', 'mourning'. Derivative form of ăg or $a \breve{g} i$ is general Turkic verb with suffix -la: ağla in Azer., ala in Turkish, ukhla in Chuvash means 'to cry', 'to weep' (Sevortian, words with vowels, 79-80). 
Irish word aes 'age' in Turkic languages has its equivalents in a word yash 'age' in Turkm., Turk., Azer., Kyrg., Kaz., Tat., Uzb. Primary meaning of a word 'yash' 'raw', 'unripe', 'wet', 'fresh' was accepted by Closon and Doerfer, in addition, Closon imagined evolution of semantics of a word 'yash' this way: 'fresh' - 'green' - 'raw, unripe' - 'wet exudation' - 'tears'; 'every new year' - 'age of somebody's life', and Doerfer admitted transformations like 'raw, unripe' - 'tears'; 'fresh' - 'young' - 'age' (O'Reilly, 11; Sevortian, with letters 'Zh", "Y", 162-163).

Azer. word tokhtag'silent', 'quiet' has affinity with Irish tochd, tochdach 'silent'(O'Reilly, 523). G. Geybullayev comparing name of Cimmerian king Tugdamme with a leader or khan of the Golden Horde, writes that "Tugdamme was a king of Cimmerians and Saca tribes. Strabo gives a name of Tugdamme as Ligdamis. If in a name Tugdamis, a suffix 'is' is not of Greek origin, then this name is identical with a name of khan of the Golden Horde in XIV c. Tokhtamish. The name Tokhtamish in Turkic languages consists of a word tokhta 'tolerate', 'calm down' and an ending 'mish'. This name was characteristic among Turks (Geybullayev. Ancient Turks, 63-64). Names of Cimmerian and Saca king Tugdamme and a leader of the Golden Horde Tokhtamish have a meaning of 'a tolerate', which semantically close to Irish word tochd, tochdach 'silent'.

Words connected with "fire", "light" in Irish language are the following: aodh, goar, gogar, geala, cuil, cal. Irish word aodh means 'fire' (O'Reilly, 33) and has its equivalents in Turkic languages: in Turk., Turkm., Kaz., Kyrg., Altai, Khakas languages a word $\boldsymbol{o t}$ is 'fire', in Azer. it is $\boldsymbol{o d}$, in Tat. and Tuvan languages a word $\boldsymbol{u} \boldsymbol{t}$ means 'light' (Sevortian, words with vowels, 483). So, all these words are homogeneous with Irish aodh 'fire'.

Charles Vallancey derives name Aidan from Irish aodh "fire". He wrote: "Why may not Odin be derived from Aodhan or Aodhon, another name in Irish for fire and the sun, from Aod, fire?" (Vallancey. Prospectus of a dictionary, 157). Azerbaijani and Turkish male name Aydin "pure", "clear" has a semantic affinity with Irish Aidan.

So, if Odin and Aidan are synonymous names, then ancestors of Scandinavians and Celts were the same. In Sweden, there is a town Sigtuna, which bare a component "sig" in its name and possibly means "a town of Sig or Saca tribes". Then, Odin was a leader of Saca tribes, who led his nation through the Caspian Sea, Volga River, and at last they reached the Scandinavian lands.

In accordance with opinion of Ch. Vallancey English word glass is of Celtic origin, from a word glaoine. He states: "The very word glaoine or gloine, the Celtic name for glass, being a Celtic and not of foreign extract, seems to prove the art to have been their own. The etymology of the word seems to be geala or glao-theine, i.e. glued or brightened in the fire" (Vallancey. A grammar of the Iberno-Celtic, 109).

In Irish language there are several words, bound with notions of "clear", "whiteness" and "brightness". For example, a word gealadh 'whiteness', gealach 'the moon', gealta 'whitened', gle-ghlan 'bright', 'clear', glegheal 'very bright', 'clear', gleal 'exceeding white' or 'clear'. All these words have similarity with Azer. gala 'fire up'. (O'Reilly, 273-283).

It is known, that the main component which takes part in making a glass is quartz sand. In order to get a transparent monolith from nontransparent and flowing product it is heated to a very high temperatures, sometimes it is $1600^{\circ} \mathrm{C}$ (41).

We suppose that the process of making a glass includes a heating of quartz sand and it is called gala 'fire up' or 'heat up'.

Consequently, a word glass derives from Celtic geala 'glued' or 'brightened in the fire' and have a semantic similarity with Azer. word gala 'fire up'.

Ch. Vallancey mentioned that ancient Irish had a special palce ceill, cill "a place of devotion, where the sacred fire always burned", another meaning of a word ceill is "a round tower", "a fire tower". A word cuilteach "a steeple, i.e. a fire house", where cuil and derivative words cuil, cal, cail, ceil means from Irish 'to burn', and teach is 'a house' (Vallancey. Prospectus of a dictionary, 169-170). These words have semantic similarities with Azer. gala 'fire up'.

Irish words goar and gogar means "light" (O'Reilly, 287) have similarities with anc. Turkic qoyur (qoqur), qovur "to roast", "to heat" (Ancient Turkic Dictionary, 452,462), Azer. qovur, Turk. kavur, Kaz. kuvir, Tat. kuir, Kyrg., Altai $\boldsymbol{k u r}$ (Etymological dictionary of Turkic languages: with letters "K", "K”,175).

Somatic vocabulary in Irish and Sc.Gael. is represented by words cluas 'ear', Welsh clust, capat 'head', mam, mama 'breast', cos 'leg', 'foot', gab 'mouth', sron'nose', muin 'the back', 'the neck'. All these words have semantic similarities in Turkic languages. 
Irish, Sc.Gael. cluas 'ear', Welsh clust (37) have affinity in Azer. gulag 'ear', Turk., Kaz. Kyrg. kulak, Turkm. gulak, Tat. kolak, Uzb. kulok (Etymological dictionary of Turkic languages: with letter "K”,189).

Irish capat "head" corresponds to Turk. kafa 'head'. Azer. word gapag 'cap', 'cover', 'upper part', 'top' semantically coinsides with Irish capat 'head' (O'Reilly, 102).

As we have mentioned previously, Sc.Gael. and Irish word mam, mama 'a breast' has affinity with Azer. mama 'a breast', Turk. meme, Tat. memi.

The notion of "nose" in several Turkic words is given in various ways: Azer., Turk., Turkm., Uzb. burun 'nose', Tat. borin, Kaz. murin, Kyrg. murun (Sevortian, with letter "B", 269-270). In Irish and Gaelic it is sron "nose" (37). In these words one can watch a process of shifting a sound $b$ into $m$ and $s$ : burun- murun - sron.

Sc.Gael. muin 'the back', Irish muin 'back', 'neck', Welsh mwn 'neck' (37) corresponds to anc.Turk. bojun 'neck', Azer., Turk., Turkm. boyun; Uzb. boyin, Kyrg. moyun, Tat. muen, Kaz. moyin (Sevortian, with letter "B”,180). As it is seen Irish muin 'back', 'neck', Welsh mwn 'neck' has similarity with Kyrg. moyun, Tat. muen, Kaz. moyin. It witnesses that Irish word muin is a primary form which is saved in Turkic languages in the form of moyun/muen/moyin. If we take into consideration a fact that ancestors of Celtic race lived on the territory of Middle Asia and was called Saca tribes, then it could not seem improbable a coincidence of the above mentioned words.

Sc.Gael. cas, Irish cos, Old Irish coss, Welsh coes 'foot', 'leg' (37) has equivalent with Azer. gich 'leg'. At the same time in Turk., Tat., Kyrg., Uzb. dialect kach, in Azer.,Turkm. qach, Kaz. kash have a meaning of 'run', 'run away', 'escape'(Etymological dictionary of Turkic languages: with letters "K", "K”, 340-341).

Irish gab 'mouth' and gabaire 'a prater', 'tattler', Sc.Gael. gab 'a tattling mouth' (37) in Azeri language has its equivalents like gap 'talk', 'conversation'; gop 'tattle', 'twaddle', gopchu 'tattler'.

Words with notion of "death", "attack", "seizing" in Irish and Sc.Gael. languages are presented by words bas, bath, comart, casar, tall, talladh, dogadh, tabaid.

In Sc.Gael.and Irish bas means 'death' (37). In anc.Turk. bas is 'attack', 'subdue', in Azer., Turk., Turkm., Tat., Kyrg., Kaz. bas 'press', 'step on smth.' A word baskin in Azer., Turk., Tat. means 'attack', 'raid'(Sevortian, with letter "B", 76).

In Sc.Gael. bath 'drown', in Irish bath 'drown', 'death', 'murder', 'slaughter', Welsh boddi 'drown' (37) have similarities in anc.Turk. bat 'drown', in Azer., Turk., Turkm., Tat., Kyrg., Kaz., Uzb. bat 'drown', 'go down'. At the same time an Irish word bothach 'a bog', 'a fen', 'a marshy place'(O'Reilly,72) has equivalents in Turk. batak, Azer. bataglig, Tat. batkak 'a bog' (Sevortian, with letter "B", 79-80).

Irish comart 'death', 'killing' (O'Reilly, 138) in Azer. is expressed by a word gebermek 'die', 'perish', but gebertmek means 'to kill'. Equivalent to this verb is Turk. gebermek 'to die'.

Turk. and Azer. verb gommek means 'bury', 'dig into', 'hide one's talents in a napkin'. In other Turkic languages a word gom means 'bury', 'dig into' in Turk., Turkm; in Tat. kum, in Kaz., Kyrg. kom. One can see semantic similarity between Irish comart 'death', 'killing' and Turkic gom/kum/kom 'bury', 'dig into' (Etymological dictionary of Turkic languages: with letter "K", 70-71).

Irish casar means 'a hammer', also casar, casarach is 'a slaughter' (O'Reilly, 105). In Turkic languages a word kas have several meanings: Azer., Turk., Turkm., Kaz., Kyrg., Uzb. kes, Tat. kis, Chuvash kas 'cut off', 'cut'(Etymological dictionary of Turkic languages: with letter "K", 55-56).

A word gusair in Sc.Gael. means 'sharp', 'keen', 'strong', Irish gusmhar, strong; from gus 'force', 'smartness' (37). Celtic word gus 'force' is coincided with Azer., Turk. guch 'strength', 'power', Tat., Kyrg., Uzb. kuch, Kaz. kush, Altai kus (Sevortian, with letters "V", "G" and "D", 96-97).

Irish word for taking, seizing, robbing, dispossessing is tall, talladh (O’Reilly, 504) which has semantic similarity in Turkic languages. For example, anc. Turk., Azer., Turk., Kaz. Kyrg., Altai tala, 'devastate', 'reive', 'destroy', Chuvash tula'reive', 'take off', Mongolian tala' rob' (Fedotov, 244).

Irish word toll 'a hole', 'hollow', Welsh twill 'an orifice', 'a hollow' (O’Reilly, 527) have equivalents in anc. Turk. telik 'a hole', 'hollow', 'leak', Azer. delik 'a hole', 'a slit', 'leak' (Ancient Turkic Dictionary, 550).

Sc.Gael. gabh 'take', Irish gabhaim, Old Irish gabaim, gaib, Welsh gafael, 'prehension' (37) have their equivalents in Azer. gap 'take', 'grab', Turk., Tat., Kaz.,Kyrg., Uzb. kap (Etymological dictionary of Turkic languages:with letters “K”, “K”, 254). 
Irish word dogadh 'conflagration', 'scorching'; 'mischief' (O'Reilly, 194) has its equivalent in Turk. tokat 'box on the ear'. In Azer. a verb toggushmaq means 'come into conflict", "collide". All these words are semantically the same.

Sc.Gael. tabaid 'fight', 'brawl'(37); Irish tabaid 'a fight', 'broil', 'quarrel' (O'Reilly, 498) are similar to Azer., Turkm. dava 'fight', 'scandal'(Turkmen-Russian dictionary, 241), Turk. dava 'a lawsuit', 'law case' (Turkish-Russian dictionary, 123). We suppose that English word debate is of Celtic origin from tabaid 'fight', 'brawl' and at the same time is of Turkic also. This word is similar to Azer., Turkm dava 'fight', 'scandal'. It could be possible to assume that people in past settled a dispute by fighting with each other.

Words which express titles in Irish are the following: ceann, seanathair, bag, righ, tigherna.

Irish word for "head", "chief", "leader", "captain" is ceann (O’Reilly, 109). In ancient Turkic: han, kan, qan means 'chief', 'leader'. In Turkic languages the word han/khan/kan is used in the meaning of 'a lord', 'a chief'. In anc.Turk. language a word gan/khan has a similar meaning with Irish ceann 'a ruler', 'a governor', 'a leader' (Ancient Turkic Dictionary, 636).

It is known that the word "senator" is of Latin origin which means "member of the senate," from senex "old", "old man" (40). We suppose that the word "senator" is of Celtic origin borrowed by Romans from Celts or Galls. In Irish language a word seanathair 'a grandfather', 'an elder' consists of two words: sean 'an ancestor', 'old', 'ancient', 'prosperity', 'happiness' and athair 'a father'(O'Reilly, 449). So, the word seanathair besides its basic notion 'a grandfather' also was used in the meaning of "a wise man" or "a man of knowledge". Celtic society mostly considered seanathairs' opinion and advices. This system of ruling borrowed from Celts or Gauls transferred to Romans together with a word seanathair later changed to senator. In Azerbaijani and Turkish languages a word san means 'glory', 'fame', 'honour' and a word ata is 'a father' in most Turkic languages. The full meaning of a word in Azerbaijani language will be 'an honourable father' or 'glorious man', which has a semantic similarity with Irish word seanathair.

Irish words bag 'a prince'and bagh 'strength', 'power'(O'Reilly, 45) have a semantic paralel with several Turkic words: Azer. bay, Turk., Tat., Altai bey, Kyrg. bek 'a lord'. In Azer., Tat. a word bay/bey means also 'a nobleman' (Sevortian, with letters "B", 97-99). In anc.Turk. language a word beg has several meanings 'a ruler', 'a leader', 'a lord', 'a husband', but a word begäč means 'a prince' (Ancient Turkic Dictionary, 92).

An interesting ethymology of a word bag is given by F. Agasioglu. He supposes that a word bag is a theonym and he connects it with shamanism. The traces of shamanism is seen in the following words bagchi, which means

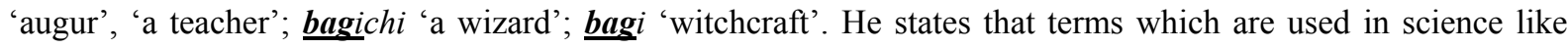
magism, magic are connected with a word bag/mag (Agasioglu. Azer people, 290).

One of felicities of a shaman is his talent of a poet and a singer (storyteller). According to E.V. Revuninkova in many cultures shamans were poets, and also performers of legends and eposes (38).

Celts also had their shamans represented by filids. Filids told different legends and eposes and considered as honourable people in Celtic society.

So, Irish words bag 'a prince'and bagh 'strength', 'power' trace back to witchcraft, shamanism. We suppose that the title bag 'a prince' was given to druids-shamans, i.e. those who had a power bagh in foretelling the future. Irish kings usually were sons of druids and possibly were called bags 'princes'.

At first sight Irish word $\boldsymbol{r i g h}$ 'king', Sc.Gael. righ, Welsh $\boldsymbol{r h i}$ (37) is needless to say that of Latin origin from $\boldsymbol{r e x}$ 'a king'.

Thomas Stratton claims the opposite. He states that the name Adiatorix, a governor of Galatia is of Celtic origin. Thus, according to his opinion, the last syllable - rix is a common termination of the names of Celtic kings and chiefs, and is the Gaelic righ, from which is derived the Latin rex (Stratton, 53).

In actual fact, a word rex or righ is of Turkic origin. Thus, Yu.Drozdov considers that all names of Gothic kings like Alarig, Ardarig, Atalarig, Gadarig, Germanarig, Gunerig, Teodorig and etc. are formed by a single grammar scheme: a nickname plus a word arig or erig, which is corrupted form of ancient Turkic word ariy (arig). In this context the word is translated as 'a noble'. It was not a title, but an honorific title, which was characteristic to the upper family class. He states that a word 'rex' is corrupted ancient Turkic word arig/ariy - 'noble', 'pure' (Drozdov, 115).

F. Agasioglu mentions a name of Saca tribes' leader Khanaziruk (Agasioglu, Ancient Turkic land, 16). One can say that this name consists of three words: 'khan', 'az', and 'iruk', where a word khan/ceann in Irish and Turkic languages means 'a leader', a word $a z$ is a name of this leader and iruk is a word 'rig', i.e. 'a king'. So, the name of 
Saca tribes' leader Khanaziruk could be translated as 'a King Az/Aza'. If we take into consideration a Turkic ethymology of the name, then it could be translated as "a noble ruler Az/Aza".

So, the name of Khanaziruk both in Irish and Turkic languages has a similar meaning.

Sc.Gael. tighearn, tighearna 'lord', 'master', Irish tighearna, Old Irish tigerne, Welsh teyrn, Old Welsh tigern (37) have affinity with Turkic name of god Tanri. According to F. Agasioglu, if Etrurians considered their ancestor Tarkan, then in Scythian mythology their ancestor was Targitay or Tanritay 'godlike', 'demigod' (Agasioglu. Azer people, 298).

So, Sc.Gael., Irish tighearna/tigern and Welsh teyrn 'lord', 'master' semantically close to Turkic Tanri 'God'.

Words with notion of "clothes" in Irish language are presented by words conach 'a shirt', tona 'a shirt, a short garment, a covering', crios 'a belt', 'girdle', 'band' (O'Reilly, 114, 155, 528). In Sc.Gael. crios is also 'a belt', 'a girdle', Welsh crys 'shirt' (37). There is a semantic similarity between Irish conach 'a shirt' and Azer. koynak 'a shirt', 'a blouse', 'clothes', 'a garment', Turkm. koynek, Kyrg. keynek 'a shirt', 'a dress', Turk. gomlek, Tat. kulmek, Kaz. keylek, Uzb. kuylak, Altai kunek 'a shirt' (Etymological dictionary of Turkic languages: with letters "K”, “K”, 89-90).

It is possible to assume the version that once in the past Azer. word koynak 'a shirt' , 'a blouse', 'a clothes', 'a garment' was similar to Irish conach and Altai kunek, because a word gon in Azer. means 'a skin'. Semantics of words in Irish conach, Altai kunek and Azer. koynak 'a shirt' is similar, in which suffixes-ach/ek/ak form an adjective from a noun gon 'a skin'. Therefore, words conach, kunek and koynak were used in the meaning of 'skin covering'.

Irish tona 'a shirt', 'a short garment', 'a covering' (O'Reilly, 528) has affinity with Azer., Turk., Turkm. word don 'dress', 'garment', 'covering', Kaz., Kyrg., Altai, Uzb. ton, Tatar tun 'clothing' (Sevortian, with letters"V”, "G”, "D", 262-263).

Sc.Gael., Irish crios 'belt', 'girdle', Welsh crys 'shirt' (37) in Turkic languages is used in the meaning of 'a belly', 'a paunch'. For example, in Turk., Kaz., Kyrg., Tat. kursak is used in the meaning of 'a belly', 'a paunch'(Etymological dictionary of Turkic languages: with letter "Қ”,164-165). In anc.Turk. a word qurša means 'belt', 'girdle' from a verb qurša 'gird', 'engird'; in Azer. gurshag is 'weist', 'belt' (Ancient Turkic Dictionary, 468).

Therefore, Gaelic, Irish crios 'belt', 'girdle' semantically coincides with anc.Turk. qurša 'weist', 'belt'.

Words which express "plow", "agriculture" in Irish and Sc.Gael. are the following: Sc.Gael., Irish arbhar'corn', Early Irish arbar; Old Irish arbe (37). Irish arbhar means also 'grain of any kind' (O'Reilly, 36). In Turkic languages a word arpa means 'barley'. We suppose that Irish arbhar 'grain of any kind' semantically similar to Turkic arpa 'barley'. (Sevortian, with vowels, 176).

Irish words for ploughshare, utensils for ploughing is arach, but a word arathar means 'ploughing', 'cultivating' (O'Reilly, 36). Gaelic and Irish word for bread is 'aran' (37). Azeri word orakh 'reaping hook' is similar to Irish arach "ploughshare".

In formation of Irish words arach 'ploughshare', 'utensils for ploughing', arathar 'ploughing', 'cultivating', aran 'bread' participates the formant 'ar', which is homogeneous with anc.Turk. word or "reap", "mow". Z. Hasanov states, that existence of component ar in Turkic languages attaches significance to words connected with plants and agriculture. Various sciences, in particular, linguistics testify that ancient Turkic peoples were familiar with various agrarian cultures (grain-growing, winegrowing, agriculture). Ancient words with the first syllable of ar: orakh (sickle), aral (plow), arpa (barley) don't raise any doubts. In mythology of Turkic peoples, protectors of trees and herbs were spirits Ar/Ereke and Ereni. In Sakha mythology Ar/Ereke were spirits, which protected trees and herbs. Ereni in Turkic mythology are spirits - protectors, presented in the form of spirits of dead ancestors, in image of plants and trees (Hasanov, 213).

All the above mentioned words are connected with Turkic word yer 'earth', because from earth grow all plants and trees. People tilled the earth 'yer' by utensils arach 'ploughshare', where -ach is an ending used in word formation, so 'ar' is closely connected with Turkic word yer 'earth'.

Well-known Danish paleoethnobotanist Hans Helbaek has discredited the myth that the agriculture originates from fertile flat territories of Mesopotamia and Egypt, and that Anatolian agriculture developed much later. H. Helbaek has proved that along with peas, lentils, many kind of fruit and bean plants, the native land of wild wheat and rye 
was on territories of Taurus and Zagros mountains. These plants were not imports to Anatolia or Transcaucasia; on the contrary, they were local products that have extended thence worldwide (Feigl, 11).

Therefore, agriculture originated first on the territories of Transcaucasia and Anatolia. Our opinion is that from those regions ancestors of Irish people carried this culture to the British Isles and improved it.

Today modern DNA tests also prove the origin of Irishmen from Asia Minor. Thus, Leicester University scientists Patricia Balaresque, Mark Jobling, Turi King and their colleagues examined the genetic diversity of the Y chromosome - a package of DNA, which is passed down more or less unchanged from father to son.

The male lineage in question, known as R1b1b2, is most common in Western Europe, reaching frequencies of $90 \%$ or more in Ireland, Wales and Spain. However, while this lineage reaches its highest frequencies on the Atlantic fringe, the researchers found that the genetic diversity within it increases as one moves east - reaching a peak in Anatolia (modern Turkey).

While R1b1b2 is most common in Western Europe, some other lineages thought to have been brought into Europe by Neolithic farmers tend to be most frequent in the Near East, where the farmers started their journey. Their frequency in populations drops as one moves from the south-east to the north-west of the continent, the route taken by the agriculturalists (39).

So, Irish words arach 'ploughshare', 'utensils for ploughing', arbhar 'corn', arathar "ploughing", "cultivating", aran "bread" testify migration of Irish people from territories of Azerbaijan and Anatolia.

In accordance with A. Korolev, vocabulary of Irish language underwent different changes by scribes of ancient texts. He states that scribes tried to modernize or "correct" an old text. A scribe replaced every old letter 'e' to 'ea', 'i' to 'io', intervocal and auslaut $b, d, g$ into $b h, d h, g h$ and etc. (Gadjiyeva, N. Z., Juravlev, V. K. Comparative Historical study of different language families, 121).

If we take into consideration facts given by A. Korolev about distortion Irish words by scribes, then we will try to reconstruct a primary look of Irish words. For example, instead of words athair, arbha, gealadh, tighearna, gabhaim, ceann we can see more ancient forms of words atair/atar, arba, gelad, tigerna,gabaim, cenn and so on.

Thus, all the above mentioned words in Scottish Gaelic, Irish and Welsh are semantically similar to Turkic ones. It testifies the fact that Celtic language was a primary branch of Japhetic or Turanian language, because it could preserve more primitive form of words. Modern DNA tests also prove the early migration of Celtic race from Anatolia (modern Turkey).

Austrian scientist Erich Feigl in his work wrote that Greek culture is indebted to Anatolian: "Turks and proto-Turks have lived for centuries in Anatolia, Caucasus and, of course, Central Asia. The Greek culture made such impressive progress due to the cultural advancements of the Turkic peoples from Anatolia in time immemorial. The incontrovertible material evidence supporting this fact is Chatal Hoyuk, Gobekli Tepe and Gobustan. The Pantheon as well as Greek gods like Aphrodite and Zeus can be considered a striking example of the influence Anatolia beliefs had on Greek culture. The Gobustan rock paintings on the coast of the Caspian Sea in Azerbaijan, and also rock paintings in the Van region, in Hakkari and Zagros mountains unequivocally prove settlement in this region of the Proto-Turks throughout the past 10,000 years" (Feigl, 55).

\section{Conclusion}

Thus, we don't know exactly when the migration process of Irish, Scots and Welsh began. Separately Irish or Erin belonged to Aran tribes, Scots and Galls to Albanians and Welsh to Cimmerians. So, Aran, Albanian and Cimmerian tribes were of Turkic origin. All these tribes entered to Saca-Cimmerian union. There is no a big difference between Irish, Gaelic and Welsh, because Saca and Cimmerian language belonged to a single proto-language. We suppose that this proto-language is Japhetic or Turanian language. In ancient times Celts settled the territories of modern Azerbaijan, Iran, Turkey, Middle Asia and Eurasian Steppes. Similarities of words and their meaning in Irish, Scottish Gaelic and Welsh as well as in Azerbaijani and other Turkic languages indicate on common origin of these nations.

\section{References}

Agasioglu, F. (2000). Azerpeople. Agridag. Baku.

Agasioglu, F. (2006). Ancient Turkic land. Saca-Cimmerian tribes. Chirag. Baku.

Ancient Turkic dictionary. (1969). Nauka. Leningrad.

Azerbaijan history. (2009). Chirag. Baku.

Azerbaijani toponyms. (2009). Encyclopedic dictionary. Baku. 
Blair, B. (2011). Thor Heyerdahl, Beyond Borders, Beyond Seas: Links to Azerbaijan. Azerbaijan International and Western University, Book VII, Exploration Series. Mega Print, Istanbul.

Bourke, C. (1887). Pre-Christian Ireland. Dublin.

Drozdov Yu., N. (2011). Turkic-speaking period of European history. Litera.Yaroslavl.

Etymological dictionary of Turkic languages. (1997). Common Turkic and Interturkic stems starting with letters "K", "K”/Authors of dictionary entries Levitskaya L.S., Dybo A.V., Rassadin V.I. Moscow.

Etymological dictionary of Turkic languages. (2000). Common Turkic and Interturkic stems starting with letter "K”/Authors of dictionary entries Levitskaya L.S., Dybo A.V., Rassadin V.I. Moscow.

Etymological dictionary of Turkic languages: (2003). Common Turkic and Interturkic stems starting with letters "L", "M", "N", "P", "S". Vostochnaya Literatura RAS. Moscow.

Fedotov, M. P. (1996). Etymological dictionary of Chuvash language. Cheboksari.

Feigl, E. (2011). The land of fire on the Silk Road - History of Azerbaijan. AzerTAc. Baku.

Gadjiyeva, N. Z., Juravlev, V. K., \& Kumakhov, M. A. (1998). Comparative historical study of different language families. Theory of linguistics' reconstruction. Nauka, Moscow.

Geybullayev, G. (1992). Ancient Turks and Armenia. Azerneshr. Baku.

Geybullayev, G. (1994). History of formation of Azeri Turks. Azerneshr. Baku.

Hasanov, Z. (2002). Royal Scythians. Liberty Publishing House. New York.

History of Azerbaijan. (2009). Aliyarli. "Chirag”. Baku.

Kazimov, G. (2003). The history of the Azerbaijani Language. Tehsil. Baku.

Maclean, L. (1873). The History of the Celtic language. London: Smith, Elder, and Co.; Edinburgh: M'Lachlan, Stewart, and Co.; Glasgow: Dugald Moore. MDCCCXL. Library of University of Toronto.

Macpherson, J. (1768) Critical dissertations on the origin, antiquities, language, government, manners, and religion of the ancient Caledonians, their posterity the Picts, and the British and Irish Scots. Dublin.

Milne, J. (1912). Celtic place names in Aberdeenshire. "Aberdeen daily journal” office. Aberdeen.

O’Reilly, E. (1864). An Irish-English dictionary. Dublin.

Sevortian, E. V. (1974). Etymological dictionary of Turkic languages: Common Turkic and Interturkic stems starting with vowels/AN SSSR. Institute of Linguistics, Nauka. Moscow.

Sevortian, E. V. (1978). Etymological dictionary of Turkic languages: Common Turkic and Interturkic stems starting with letter "B"/AN SSSR. Institute of Linguistics, Nauka. Moscow.

Sevortian, E. V. (1980). Etymological dictionary of Turkic languages: Common Turkic and Interturkic stems starting with letters "V", "G" and "D"/(Gadzhieva N.Z. ed.)/AN SSSR. Institute of Linguistics. Nauka. Moscow.

Sevortian, E. V. (1989). Etymological dictionary of Turkic languages: Common Turkic and Interturkic stems starting with letters "Zh", "Y"/Authors of dictionary entries Sevortian E.V., Levitskaja L.S. Moscow.

Stratton, T. (1870). The Celtic origin of a great part of the Greek and Latin languages, and of many classical proper names, proved by a comparison of Greek and Latin with the Gaelic language or the Celtic of Scotland (2nd ed.). Edinburgh.

Tunchay, B. (2010). The language and literature of Caucasian albans. Ganun. Baku.

Turkic-Russian dictionary. (2005). R.R. Yusipova. Media. Moscow.

Turkmen-Russian dictionary. (1968). Soviet Encyclopedia. Moscow.

Turner, S. (1823). The history of Anglo-Saxons: comprising the history of England from the earliest period to the Norman conquest (4th ed.). London.

Vallancey, C. (1802). Prospectus of a dictionary of the language of the Aire Coti, or ancient Irish. Dublin.

Vallancey, C. (1818). An Essay on the antiquity of the Irish language; being a collation of the Irish with the Punic language. London.

Vallancey, C. (1964). A grammar of the Iberno-Celtic or Irish language (2nd ed.). Library of University of Oxford. Dublin. 
http://ru.karabakhinfo.com/ru/arasdirma/90-esche-odna-armyanskaya-falsifikaciya-chi-predki-yafes-i-togarma-h aev-ili-tyurkov.html

http://www.ceantar.org/Dicts/MB2/index.html

http://92.46.62.214/articles/view/133

http://news.bbc.co.uk/2/hi/8467623.stm.

http://www.etymonline.com/index.php?term=senator

http://mastter.ru/225-iz-chego-delajut-steklo.html

\section{Copyrights}

Copyright for this article is retained by the author(s), with first publication rights granted to the journal.

This is an open-access article distributed under the terms and conditions of the Creative Commons Attribution license (http://creativecommons.org/licenses/by/3.0/). 